\title{
Curriculum Structure and its Influence on Content Knowledge of Economics Student Teachers
}

\author{
Mothofela R Msimanga \\ University of the Free State, South Africa \\ https://orcid.org/0000-0001-5858-7973
}

\begin{abstract}
This study explored how the curriculum structure of the Bachelor of Education in economics teaching qualification at one South African university impacts on content knowledge of economics student teachers. Document analysis was undertaken on the university's Faculty of Education prospectus. Due to meetings restrictions during lockdown, email focus group interviews were conducted. Ten fourth year economics student teachers participated in the study. The study adopted social transformation theory as a theoretical framework. Data was thematically analysed. Data revealed that economics student teachers study the subject content that is meant for economists and other economics related careers. The subject content that is not relevant to school curriculum economics negatively affects content knowledge needed during work-integrated learning and in in their teaching career. For this reason, the curriculum is unfairly structured. To strengthen the content knowledge of economics student teachers, the study recommends that a relationship between economics content in academic major modules and school curriculum economics content be formed. Secondly, economics academic major modules should expose economics student teachers to an introduction in economics content as a way of advancing their subject content knowledge but the focus should be more on school curriculum economics content.
\end{abstract}

Keywords: academic major modules; curriculum structure; subject content knowledge; economics teaching; social transformation theory

\section{Introduction}

There has been a call in South Africa for the reintroduction of teachers training colleges. The basis for the call follows from the claim that universities produce teachers who are not ready to teach because they lack pedagogical content knowledge (PCK). The aim of the study was to explore how the curriculum structure of the Bachelor of Education in economics teaching qualification at one South African university impacts on content knowledge of economics student teachers. To achieve the aim of the study, the curriculum structure of the Bachelor of Education in economics teaching qualification and its impact on content 
knowledge of economics student teachers were examined. The study was conducted at a South African university to investigate the relevancy of the content presented in economics academic major modules to the content that student teachers are expected to teach during work-integrated learning (WIL) and in their teaching career. It also explored the implications of the Bachelor of Education in economics teaching qualification curriculum structure on content knowledge of economics student teachers. The study was guided by the following research questions: How is the Bachelor of Education in economics teaching qualification structured? What is the relationship between the content presented in economics academic major modules and school curriculum economics? What are the implications of the Bachelor of Education in economics teaching qualification curriculum structure on content knowledge of economics student teachers? The study will make a contribution by determining whether the Bachelor of Education in economics teaching curriculum is structured in a manner that improves content knowledge of economics student teachers and make necessary suggestions. The findings and recommendations of the study might be used to structure the curriculum in a manner that will improve content knowledge of student teachers.

\section{Teacher education}

Teacher education is the education that equips prospective teachers with skills, knowledge, values, and behaviours required to effectively perform expected tasks at schools and in the community (Mondal, Saha, \& Baidya, 2015). It is professional education that ensures teachers meet the needs of society in an efficient and effective manner at any point in time (Osuji, 2009). It is based on policies and procedures designed for such a purpose (Mondal et al., 2015). Teacher education is offered formally or informally (Osuji, 2009), as pre-service education and training for student teachers or in-service education and training for working teachers (Katitia, 2015; Osuji, 2009). It aims at exposing pre-service and in-service teachers to new ideas and practices which makes them better teachers (Katitia, 2015). According to Islam (2012), there are gaps in teacher education which lead to inconsistencies. Such inconsistencies include teacher education being unable to produce adequate numbers of quality teachers because they focus more on meeting departmental prescriptions (Chisholm, 2009). The study conducted by Bahr and Mellor (2016) found that in Australia the inconsistencies in teacher education originate from the fact that teacher education programmes are highly theoretical, impractical, and disconnected which leads to poor quality teaching, whereas in South Africa, university education is very abstract and too theoretical (Chisholm, 2009). Teacher education is a professional education offered to prospective and in-service teachers to meet the needs of society. There are inconsistencies in teacher education which need to be addressed to achieve the purpose of teacher education and one of the inconsistencies is the quality of teachers.

Chaka and Govender (2017) postulate that in Nigeria, colleges of education are crucial in providing teacher education. There is a call in South Africa to re-open teacher education colleges to overcome the challenge of teacher education that is not producing quality teachers in adequate numbers (Chisholm, 2009). But, Chisholm (2009) argues that re-opening of teacher education colleges is not the 
solution to the challenges because such calls are mainly against provision of teacher education at higher education institutions, rather than improving teacher education. The study conducted by Deacon (2016) found that there was no problem if teacher education is provided by universities because they are able to equip prospective teachers with pedagogical content knowledge. But, Mahabeer (2018) argues that the teacher education curriculum which is currently offered at higher education institutions is too theoretical and inconsistent with school curriculum, thus, it supplies teachers of low quality (Thaba-Nkadimene, 2017). This is also the perception in South Africa. Yet, there are also differing views on this perception, thus this study looked into this matter.

\section{Teacher education and quality of teaching and learning}

Teacher education is expected to produce teachers who can improve the quality of teaching and learning in schools (Geduld \& Sathorar, 2016). This can be achieved when higher education institutions produce committed, professional, and well-qualified teachers (Du Toit, 2011). There are concerns regarding poor teacher education which produce low quality teachers who in turn offer low quality of teaching and learning (Nomlomo \& Sosibo, 2016). In congruence, Mashau, Mutshaeni, and Kone (2016) state that there are challenges in South African teacher education which amongst others include quality and relevancy of teacher education. Therefore, teacher education should be reconceptualised to address the concerns about the low quality of teachers which affect the quality of teaching and learning (Mahabeer, 2018). This will help to produce quality teachers, as quality of teaching and learning depends on quality of teachers (Osuji, 2009). In order to produce high quality teachers who can improve teaching and learning at schools, teacher education programmes should be well-designed (Thaba-Nkadimene, 2017). According to Vaillant and Manso (2013), there is no problem with teacher education but the problem lies with the structure of teacher education.

Curriculum enhances teaching and learning, therefore it should not be neglected (Boughey, 2018). Although there is an idea that underperformance at schools is caused by teacher education programmes which do not prepare student teachers for their teaching job, there is no clear evidence that teacher education produces low quality teachers and that generally, teachers do badly with regard to teaching and learning (Bahr \& Mellor, 2016). Poor performance at schools cannot be attributed to poor quality education at higher education institutions because secondary education performs poorly; additionally the tertiary education offered in South Africa is among the best in the developing world (Mlachila \& Moeletsi, 2019). The quality of teacher education is key to the quality of teachers and quality of education. Different authors posit different views about the quality of teacher education and some argue that there is no problem with the quality of teacher education but the problem is with the structure of teacher education. Therefore, this study based on social transformation theory explored the views of student teachers on how the curriculum structure impacts their content knowledge. 


\section{Initial Teacher Education in South Africa}

In South Africa, higher education institutions provide initial teacher education that prepares student teachers to work in schools (Bernstein, 2015). Bachelor of Education and Postgraduate Certificate in Education qualifications are initial teacher education qualifications offered by higher education institutions to prospective beginner teachers for specialisation in a phase and/or subject (Department of Higher Education and Training [DHET], 2015). Bachelor of Education is a four-year degree in which student teachers study to fulfil both academic and professional requirements of a qualification (Bernstein, 2015). Its programmes mirror the curriculum implemented at schools (Du Toit, 2011). The primary purpose of Bachelor of Education is to equip graduates with knowledge and skills which will enable them to be academically and professionally qualified teachers, by providing a well-rounded education that includes subject content knowledge, educational theory, and methodology (DHET, 2015). Bachelor of Education programmes should respond to societal needs and address education challenges (Du Toit, 2011). Bachelor of Education programmes include pedagogical content knowledge, practical, fundamental, and situational knowledge to achieve teacher effectiveness in the classrooms by acquiring and applying different knowledges in a cohesive manner (Geduld \& Sathorar, 2016). The study focused on a four-year Bachelor of Education qualification for student teachers following both academic and professional requirements at the same time and specialising in economics teaching.

\section{Bachelor of Education curriculum design and development}

According to the DHET (2015), the Bachelor of Education curriculum is structured in an integrated manner to include disciplinary learning, pedagogical learning, practical learning, fundamental learning, and situational learning. In South Africa, teacher education curriculum includes designs of teaching and learning and development of pedagogical content knowledge (Nomlomo \& Sosibo, 2016), whereas, in the United Kingdom, the Netherlands, Finland, and Sweden, teacher education curriculum is structured to include research, alternative qualifications, and articulation between schools and universities (Vaillant \& Manso, 2013). In the United States, teacher education curriculum includes schools and society, reading and writing, research, teaching practice (Chen \& Mu, 2010), pedagogical content knowledge, and authentic assessments that link theory and practice (DarlingHammond, 2006). In Singapore, teacher education includes amongst others school curriculum syllabus and the use of teaching materials to integrate disciplines and teaching (Chen \& Mu, 2010). Based on the aforementioned assertions, teacher education amongst others should articulate school curriculum.

Effectively developed curriculum should meet the current needs of the society served (Alsubaie, 2016). But, Booi and Khuzwayo (2019) found that there were gaps in curriculum structure, in what the curriculum structure expects from teacher knowledge, and teacher education. Student teachers who obtain a teacher qualification should be competent and effective when they apply content knowledge (Du Toit, 2011). Teacher education curriculum should help teachers to be able to continually access knowledge and carry investigations in their field of work (Darling-Hammond, 2006). A study conducted by Booi and Khuzwayo 
(2019) found that Bachelor of Education programmes in South African universities encountered hardships in obtaining accreditation as they were not competently developed. University academics were not well-equipped with curriculum design and development skills and lacked expertise in this area.

Nomlomo and Sosibo (2016) recommend that stakeholders such as student teachers, teachers, school principals, communities, and policy makers should participate in teacher education curriculum design and development. Similarly, involvement of teachers in curriculum development is key for achieving effectiveness at schools (Alsubaie, 2016). Students' involvement is also key in curriculum design (Du Toit, 2011) to ensure that curriculum is student-focused (Geduld \& Sathorar, 2016). The study conducted by Sosibo (2012) found that collaborations and networks between the university and the department of education helps to ensure that the content taught in teacher education at universities is relevant to school curriculum content. There are concerns that teacher education curriculum was not well structured and had gaps. To ensure that teacher education curriculum is well structured, involvement of student teachers in curriculum development is recommended. Thus, student teachers participated in the study to give their views of how teacher education curriculum should be structured.

\section{Teachers' subject content knowledge}

Subject content knowledge is the theoretical factual knowledge of the subject that teachers need to demonstrate their competency in and the ability of teachers to apply their subject competencies in different learning experiences (Du Toit, 2011). It is an understanding of specific subject matter relevant to the subject (DHET, 2015). Subject matter knowledge includes theories, concepts, facts, and procedures within the subject (Sosibo, 2012). In comparison to their peers, the content knowledge of South African teachers is lower and that affects effective teaching because teachers cannot teach what they do not know (Mlachila \& Moeletsi, 2019).

In a study conducted by Sosibo (2012), student teachers were also concerned about their content knowledge because their academic major subject content was not offered up to the fourth year level. This might be due to the credits allocated to the subject content knowledge, as only $50 \%$ of teacher education qualification credits focus on developing subject specialisation teaching (DHET, 2015). It is important for subject content knowledge taught in teacher education programmes to be relevant to the subject content taught at schools (Sosibo, 2012). This will help to develop teachers who possess expert knowledge and expert skills (Kimathi \& Rusznyak, 2018). Subject content knowledge is key in teacher education and there is a concern that content knowledge of South African teachers is low. This is attributed to time spent studying subject content and irrelevancy of subject content studied at universities when compared to the school subject content. The study looked into how change can be brought about with regard to student teachers' content knowledge. 


\section{Theoretical framework}

The theoretical framework that guided this study is a social transformation theory which is informed by the ideas of Habermas which promotes infusing social sense by promoting critical reflection, critical learning, and discursive understanding (Fleming, 2000). Social transformation is a necessary modification in the way society is organised by questioning social patterns in order to reconfigure them (Castles, 2010). It advocates for urgent attention required to address an identified problem (Aboluwodi, 2015) to bring fundamental social change through social processes (Dominic, 2011). Furthermore, social transformation is not specific on what societal change should take place (Dominic, 2011) and does not take place gradually or over a period of time (Khondker \& Schuerkens, 2014). It is achieved when there is a shift in individuals, organisations, and society's orientation that embraces new actions to achieve the results (Musa, Jimba, \& Ogundele, 2015). Historical and cultural patterns facilitate social transformation by developing change and resistance agents (Castles, 2010). This leads to structural change of culture at institutions (Machonin, 1996), as institutional and cultural changes are incorporated in social transformation (Khondker \& Schuerkens, 2014). From social transformation theory, the study mainly focuses on critical reflection done by student teachers on the curriculum structure and change that is needed if identified in the curriculum structure.

According to Brissett (2018), education and school systems are probable catalysts of transformation that support structural and individual change. Education is indispensable in achieving positive societal transformation as it brings hope to societies (Musa et al., 2015). Social transformation in education can be achieved if change occurs at multiple levels (Brissett, 2018). Teachers are central to social transformation in education as they transform learners by mediating between learners and educational content (Musa et al., 2015). Educational curriculum helps to promote transformation in education by challenging the old assumptions and developing new assumptions when necessary (Bunduki \& Higgs, 2017). When the thought process of individuals is changed, social progress is driven (Sharma \& Monteiro, 2016). Aboluwodi (2015) identified inclusion of marginalised groups of people and democratic culture as key aspects in achieving social transformation.

In this connection, teacher education is the catalyst of social transformation because if it provides quality teachers, then they will be able to transform society through learners. Curriculum structure is key for social transformation because if the curriculum is well structured, it will provide teachers who will address the needs of society. A real transformation in South African universities can be achieved when students are involved in curriculum development, as involvement of marginalised groups (students) in curriculum development can lead to real social transformation. When the content knowledge of economics student teachers is well developed, they will be able to teach the subject content in a better way which will promote social transformation for economics learners.

\section{Methodology and design}

An interpretivist research paradigm was used in this study. The paradigm is based on the assumption that reality is constructed through social interaction of 
individuals from different backgrounds and experiences in a wider social context (Wahyuni, 2012). In this paradigm, the perceptions of the participants are used to understand and interpret their viewpoints about the context (Kivunja \& Kuyini, 2017). A qualitative research approach was used to understand the perspectives of economics student teachers to discover the meaning given to the phenomena studied, as Bricki and Green (2007) assert. The participants interacted to construct knowledge by giving their viewpoint about the relevancy of economics academic major modules content to school curriculum economics content and how the curriculum structure of their teaching qualification influenced their content knowledge.

Convenience and purposive sampling were used to identify participants who understood the phenomena, were willing to participate, and available. According to Simion (2016), convenience sampling is a non-probability sampling used to select the participants who have a deep understanding of the phenomena studied and are easy to access. Furthermore, purposive sampling is used to select information-rich participants. The participants were 10 fourth year Bachelor of Education in economics student teachers from a South African university. The participants were selected from a target population of 24 economics student teachers. According to Bricki and Green (2007), an effective focus group which yields sustainable discussions is comprised of six to 10 participants. Thus, a sample of 10 participants was sufficient for the focus group in this study.

Document analysis and email focus group interviews were used to generate data. According to Mohajan (2018), qualitative research methods include amongst others document analysis and interviews. Document analysis was used to get information and understanding about the research context (Simion, 2016). The university's Faculty of Education prospectus was examined to get information and understanding of the curriculum structure of the Bachelor of Education in economics teaching qualification. To afford economics student teachers the opportunity to give their viewpoints on the influence of curriculum structure on their content knowledge, email focus group interviews were used. Email focus group interviews were used instead of face-to-face focus group interviews because of meeting restrictions put in place during the Coronavirus pandemic period. A single email focus group interview which lasted for about two hours was organised and conducted at a date and time when the participants were available. On the set day and time participants had access to their emails and internet connectivity. The researcher asked prompting questions and the participants responded to all to ensure that other participants were able to see what they had said and add on given responses when necessary. Participants gave their views on the relevancy of the content presented in economics major modules to the content that they should teach during WIL and in their teaching careers. They were also asked about the implications of the Bachelor of Education in economics teaching qualification curriculum structure on their content knowledge.

Ethical clearance was granted by the Research Ethics Committee of the institution where the study was conducted. Participants' informed consent to participate was 
sought before data generation and they were assured of confidentiality, anonymity, voluntary participation, and voluntary withdrawal without any explanation at any stage of the research process. Email focus group interviews provided data for the study and the participants were asked to delete the text of email focus group interviews at the end of the interaction process.

Data generated was thematically analysed to recognise emerging themes and identify key emerging ideas (Mohajan, 2018). Themes that were relevant to the research focus, research question, research context and the theoretical framework were identified to make the findings, as asserted by (Roberts, Dowell \& Nie, 2019). The findings were described and interpreted to make meaning. According to Korstjens and Moser (2018) trustworthiness in qualitative research is achieved through credibility, transferability, dependability and confirmability. Data was transcribed verbatim, the findings and interpretations are based on original views of the participants and university's prospectus. Methodology used is described and thick data is provided; the participants had an opportunity to confirm that truthfulness of the findings. Transcripts are kept for verification of the findings and recommendations by an independent person.

\section{Findings}

The following three findings were made based on the research question: the structure of the Bachelor of Education in economics teaching; the relevancy of economics academic major modules content to school curriculum economics content; the implications of the Bachelor of Education in economics teaching curriculum structure on content knowledge of economics student teachers. The first finding is based on document analysis and the last two findings are based on data generated during email focus group interviews.

\section{The structure of the Bachelor of Education in economics teaching}

The university offers the Bachelor of Education Degree in Senior Phase and Further Education and Training Phase (Grade 8-12). All the modules in the programme are compulsory and completed over four years on full-time study only. The qualification is aimed at producing professionally qualified teachers for Senior and Further Education and Training phases of schooling. Student teachers specialise in three specialisations which can be a combination of a Senior Phase, Further Education and Training Phase, and a support role. The qualification is organised through different domains namely: Humanities, Science and Technology, Languages, and Business and Management. Economics teaching is offered in the Business and Management studies domain. Below are the extracts from the prospectus:

Duration of the programmes: 4 years full-time study only.

Curriculum (all modules are compulsory).

The purpose of the Bachelor of Education in Senior Phase (SP) and Further Education and Training (FET) teaching is to deliver professionally qualified beginner teachers for the Senior and FET phase of schooling. This is done by providing student teachers with a well-rounded education that equips them with specialised teaching competence in at 
least three specialisations: (one SP subject and two FET subjects or one SP subject, one FET subject and one support role).

\section{Business and Management Studies, Accounting, Business Management and Economics.}

The curriculum includes subjects such as Education Studies, Teaching Studies, Methodology and Practicum, Academic Majors, English as Language for Teaching and Learning, and Academic Literacy for Education. The academic majors are offered by other faculties and those faculties are fully responsible for academic major modules. Academic majors are studied over two or three years. Students' content knowledge is developed through coursework and practicum as they learn from practice, in practice, and from service. Student teachers are responsible for teaching in their specialisation subject area during practice teaching. This is supported by extracts below from the prospectus:

Students do the academic majors with other faculties ... other faculties take full responsibility for the modules.

Through integrating coursework at the University and practicum at schools the Faculty creates learning opportunities for student-teachers to acquire sound subject knowledge.

Teaching methodology and practicum are integrated. This implies that students will engage in learning from practice, learning in practice and learning from service, aiming at developing specialised pedagogical content knowledge and teaching competence in each subject area.

During placement at schools, students will be required to take on teaching responsibilities.

Student teachers content knowledge is developed in academic major modules and teaching methodology and practicum modules help student teachers to teach the content that they have acquired from academic major modules.

The relevancy of economics major modules content to school curriculum economics content

The content taught in the first to the third year levels in economics academic major modules is not relevant to the content that student teachers are expected to teach at schools. Part of the content taught in the first year is relevant to school curriculum economics. The content of economics academic major is more complex and different from school curriculum economics. Economics academic major modules are not efficient in strengthening the content knowledge of student teachers for school curriculum economics. It does not prepare student teachers to teach effectively during WIL and in their teaching career. These assertions are supported by participants as follows:

"Economics taught in first year is more of a foundation of Economics taught in Schools." 
"There are some similarities in first year, however they are very small. Economics major is more depth and complex. Economics taught in high school is completely different."

"The content taught in the economics major and the economics content we are to teach have some similarities which are only taught at first year as an introduction to economics, however going forward the content becomes different and more complex and this makes it challenging to teach the economics content that you were not exposed to."

"The economics major module is not as efficient in teaching us the content that we teach in high school."

"The content taught in Economics major differs a lot from the high school content and as a result does not help equip student teachers for WIL or for the start of their careers as teachers."

"I believe that the relation of the Economics major to the Economics content we have to teach from next year is only at a foundational level."

Economics content in academic majors is relevant for students who are pursuing careers in economics, finance, and other related careers, not for student teachers. These modules are irrelevant to teaching career expectations but allow student teachers who are not certain about their career choice to divert to economics and other related degrees. The content is complex and for student teachers to be competent in their career they are required to study school curriculum economics content on their own to strengthen their content knowledge. This finding is supported by assertions of the participants stated below:

"The biggest challenge becomes that the levels of complexity and detail in the major are appropriate for those students who are following a career in economics or finance. It becomes less appropriate for Bachelor of Education candidates because it does not allow for simplicity, which is at the centre of teaching such a complex subject at a high school level."

"It is mainly significant for students who want to become economists, data analysts, economic researchers and investment analysts because it serves little purpose for students who will be teaching economics in high school, as it does not teach them the relevant content that they will require to teach in high school."

"I agree with you ... that the module gets irrelevant from that we're supposed to teach at schools as it moves to the other years. But the study builds on each aspect of the subject to an extent that it allows those certain education students who are not certain the field to divert to other Economics degrees."

"As a student teacher the economics that I learnt from first year to the third year did not help me understand the content I teach during my work-integrated learning practical." 
"The effects of this curriculum structure are that the major meant to prepare me as a teacher does little preparation and causes a student teacher to have to re-learn economics content for high school in order to be able to teach."

The finding from this section is that the academic major module does not develop the content knowledge of student teachers that is needed to teach school curriculum economics.

The implications of the Bachelor of Education in economics teaching curriculum structure on content knowledge of economics student teachers

Student teachers have to dedicate more time to studying school curriculum economics content because economics academic major modules do not prepare them for teaching the subject content in high schools. Student teachers spend more time learning school curriculum content and their content teaching is affected. They find it difficult to teach the subject content because they are not well prepared in school curriculum content and this creates a negative attitude towards the subject. Students who could be good economics teachers end up not specialising in the subject. The complexity of the content of economics academic major modules creates a situation where students have to work backwards in order to teach effectively and at times they confuse learners which can make them lose interest in the subject. Student teachers find it difficult to perform well in tests based on school curriculum content, and to teach the content properly during micro lessons and WIL. Student teachers face these challenges even though they have studied the subject content knowledge at different levels of their studies. This finding came from participants' views as indicated below:

"The content differs a lot and as a result, during WIL I have to dedicate more time to learning the content myself rather than teaching which also affects the way I interact with learners during Economics lesson."

"This is negative towards the methodology because students end up not taking economics as a major for their teaching career because of previous students telling them their experiences and difficulties to understand how it relates to high school work. Economics major is a barrier for students who want to teach economics because being good with economics in high school does not make you eligible to be able to qualify to teach it because the economics in higher education is a completely different type of content and application."

"When I eventually went to my work integrated learning I realized that the work we learn in the Economics Major is way more advanced than what is learnt in economics for teaching in schools. I find that I have to work backwards from Economics major to try to understand economics in teaching."

"This is evident in content tests we take in economics methodology, I struggle to do well in those because I don't have the foundation needed to partake in those but have a rather advanced level of knowledge learnt from 
Economics major which I then have to try break down and get to the answer required by the methodology test."

"It is also time consuming because it needs Economics student teachers to develop personal preparation strategies for content tests, micro lesson presentations and WIL."

"In terms of subject content knowledge as a student teacher you gain content knowledge that is too complex to deliver for learners and may lead you to become a confusing teacher because the level of complexity may lead learners to fear the subject."

Student teachers felt that the curriculum is unfairly structured because they study complex subject content that is meant for other qualifications and is not relevant to their career. The assumption in methodology modules that students have studied the subject content in academic major modules is an unfair assumption. Students are expected to juggle between two different economics subject contents. They are frustrated as they are expected to move back and forth with the subject content at different levels of complexities and study unnecessary content which needlessly increases their workload. It is unfair for students to study and pay for modules (academic majors) which do not contribute to their academic success and careers by not developing their content knowledge as intended. An academic major module which will focus on economics teaching is needed to strengthen content knowledge of economics student teachers. The participants' statements below support the findings:

"It is not fair because the knowledge is so complex in a way that it ends up making the Bachelor of Education degree to seem as difficult to obtain with economics as a major. Another factor is that the major is fetched from the school of economics were they focus on commerce career students and not education. This is an unfair enrolment for the education students because they are not catered for in the module. The faculty of Education owes itself and future students an economics major which is constructed by them. In order to ensure that the content required to be taught is known by students."

"It becomes very difficult at times because to move between the content taught at the economics major and the economics that is to be taught at schools. This is because most of the time I am exposed to the content taught in the economics major which aims to equip you with the knowledge that concerns economic activity its challenges and how to approach it. And then when I have to teach the economics content that I have to teach I have to go back to the basics first and look through it again which almost feels like I'm studying the content that I have to teach. This is not fair for student teachers because I feel like we are learning two different economics content as and it becomes a lot of work to move from one content to another."

"I find that sometimes this complexity and broadened knowledge acts as a barrier to being able to understand the economics subject knowledge in the sense that you already know what happens beyond the specific concept 
taught in schools from the economics major knowledge, making it a bit harder to backtrack to where it all started. I think it leads to teachers having difficulty breaking down and explaining simpler concepts to learners as they become a bit more difficult for them as teachers to interpret to."

"Even for micro lesson presentations, a whole new engagement with relevant documentation and textbooks is required and this is unfair because it means we are paying for a module that does not directly link with our academic success in most aspects of our degree."

"During WIL, content tests and the micro lesson we find ourselves having to dedicate time to learning the subject knowledge and trying to explain it to ourselves and this is unfair because as a student-teacher you end up having an attitude towards the methodology as you will feel like anything that has to do with it requires more time and effort to complete it."

"I constantly have to revisit the textbook to gain subject knowledge on the content I have to teach. This puts a lot of pressure on me as I have to firstly learn the subject knowledge on my own before I can teach it to high school learners."

"I had to revisit the textbook and watch YouTube videos to try and gain more insight on how to teach the content of the lesson so that I can be able to contextualise lessons to learners."

The curriculum structure of the Bachelor of Education in economics teaching is not fairly designed because it does not help student teachers to master the content knowledge they are expected to teach in schools.

\section{Discussion}

The Bachelor of Education in economics teaching is not a standalone qualification but economics teaching is offered in the Bachelor of Education Senior and Further Education and Training phase qualification. Economics teaching is offered over four years in the Business and Management Studies field. All the modules are compulsory and they focus on educational theory (Education Studies and Teaching Studies), subject content knowledge (Academic Majors) and methodology (Methodologies and Practicum). The qualification includes subject content knowledge, as Katitia (2015) alludes that it is important for teachers to understand and know the content of their specialisation subjects. The qualification adheres to the prescripts of DHET (2015) for the Bachelor of Education qualification as it includes disciplinary learning, pedagogical learning, practical learning, fundamental learning, and situational learning which are addressed by subject content knowledge, educational theory, and methodology. Content knowledge of student teachers is developed through coursework in academic majors offered at the university and practicum done at schools. Economics student teachers have the option of specialising in economics and another Further Education and Training subject or a support subject. 
The economics academic major is offered in another faculty which is fully responsible for the module. Based on this, the economics academic major does not mirror the school curriculum, as suggested by Du Toit (2011), that academic majors should mirror the curriculum implemented at schools. The content of economics offered in another faculty is not relevant to the content in school curriculum, as Sosibo (2012) highlights the importance of relevancy of the academic major content offered at the university to the school curriculum content. Student teachers can take economics as an academic major up to second year level or third year level of study. Studying an academic major subject content up to second year level can be a challenge because in a study conducted by Sosibo (2012), there was a concern from the students that the academic major subject content was not offered up to the fourth year level. The qualification is wellstructured but the subject content knowledge studied should be relevant to economics content taught at schools. Students should spend more time studying subject content to master subject content knowledge of their specialisation subject.

Document analysis findings were corroborated by the email focus group interview's findings that the content studied in academic major modules is not relevant to the economics teaching qualification but relevant for economics and related qualifications. Islam (2012) highlights that there are gaps in teacher education. Chisholm (2009) and Thaba-Nkadimene (2017) indicate that these gaps lead to producing poor quality teachers. Only part of the first year academic major module relates to the school curriculum which student teachers are expected to teach; this is corroborated by Mahabeer (2018), that teacher education curriculum is incoherent to school curriculum. Economics content studied in academic major modules does not strengthen student teachers' content knowledge and this is evidenced by their performance in content tests which are based on school curriculum. Lack of content knowledge affects student teachers negatively when they present micro lessons and teach during WIL, this in turn might affect them in their teaching career. The significance of subject content knowledge for teachers has been emphasised by Bernstein (2015) and Katitia (2015). Learners who are taught by teachers who lack content knowledge do not perform well in that specific subject.

The curriculum structure of academic major modules is unfair to student teachers as it does not address the needs of their career; this is supported by Vaillant and Manso (2013) when they indicate that curriculum structure of teacher education is problematic. It is also not fair for student teachers to pay for modules which are not relevant to their career. Student teachers spend more time studying the school curriculum content on their own, whereas they have passed the modules which were meant to prepare them in this regard. In this case, social transformation is needed to ensure that actions undertaken lead to achievement of results (Musa et al., 2015). This unfairness affects learners because learners who are taught by teachers who are not competent in the subject content cannot perform well in the subject and that affects social transformation. Brissett (2018) argues that education is a probable catalyst of transformation which means learners can be transformed through education. To overcome this unfairness and bring social transformation, students should study academic major modules which are meant for economics 
teachers to develop their content knowledge. This is supported by Alsubaie (2016) when positing that an effectively designed curriculum should meet the needs of the society it serves.

\section{Recommendations}

To achieve social transformation, the study recommends that economics teachers should possess a good content knowledge which will help them to teach the subject effectively. This can be achieved if the curriculum is well-structured. A well-structured curriculum for economics teaching studied in economics academic major modules should be related to school curriculum economics content. Notwithstanding this, student teachers should be exposed to introductory economics content to help them with advanced subject content but more focus should be on school curriculum economics.

\section{Limitations}

The findings of this study cannot be generalised because the study was only conducted in one university in a particular context. Further studies can include more universities. Due to movement restrictions during the Coronavirus pandemic period, data was collected by means of email focus group interviews instead of face-to-face focus group interviews which could have shown the reactions of participants during discussions.

\section{Conclusion}

To achieve social transformation, student teachers participated in an email focus group interview to reflect on relevancy of the content studied in economics academic major modules and its impact on their content knowledge. Student teachers reflected on the curriculum structure and made inputs on how it needs to be transformed to contribute in developing them for teaching during WIL and in their teaching careers. This can be achieved when the curriculum structure of the Bachelor of Education in economics teaching is changed to ensure that the content of economics academic major modules is relevant to school curriculum economics content. Curriculum which is properly and fairly structured is important for realisation of social transformation. Curriculum can be regarded as fairly structured when it affords economics student teachers an opportunity to study the subject content intended for economics teachers. The findings of this study can serve as a wake-up call for higher education institutions to check whether their economics teaching qualification curriculum is fairly structured and if not so, the institutions should gradually change their curriculum structure to address the problem. This can partly contribute to the realising of social transformation in higher education institutions and improve student teachers content knowledge which in turn can improve economics teaching at schools. In conclusion, the study managed to achieve its aim and objectives as stated in the introductory section. 


\section{References}

Aboluwodi, A. (2015). Education for social transformation in Nigeria. Caribbean Educational Research Journal, 3(2), 122-131. Retrieved from https://www.cavehill.uwi.edu/fhe/education/publications/pastissues/volume-3-number-2-september-2015/articles/article-akinjideaboluwodi.aspx

Alsubaie, M. A. (2016). Curriculum development: Teacher involvement in curriculum development. Journal of Education and Practice, 7(9), 106-107. Retrieved from https://files.eric.ed.gov/fulltext/EJ1095725.pdf

Bahr, N., \& Mellor, S. (2016). Building quality in teaching and teacher education. Victoria, Australia: Australian Council for Educational Research Press.

Bernstein, A. (2015). CDE technical report: Teacher supply and demand 2013-2025. Parktown, Johannesburg: The Centre for Development and Enterprise. Retrieved from https://www.cde.org.za/wp-content/uploads/2018/07/Teacher-Supply-andDemand-2013-2025-Full-Report-March2015-CDE.pdf

Booi, K., \& Khuzwayo, M. E. (2019). Difficulties in developing a curriculum for pre-service science teachers. South African Journal of Education, 39(3), 1-13. doi:10.15700/saje.v39n3a1517

Boughey, C. (2018). Using the curriculum to enhance teaching and learning. South African Journal of Science, 114(9/10), 1-3. doi:10.17159/sajs.2018/a0288

Bricki, N., \& Green, J. (2007). A guide to using qualitative research methodology. Medecins Sans Frontieres Field Research. Retrieved from http://hdl.handle.net/10144/84230

Brissett, N. O. M. (2018). Education for social transformation (EST) in the Caribbean: A postcolonial perspective. Education Science, 8(197), 1-12. doi:10.3390/educsci8040197

Bunduki, K. H., \& Higgs, L. G. (2017). Reimagining education for transformation and social change: A case study of integrated learning at UCBC in the DRC. South African Journal of Higher Education, 31(1), 14-28. doi:10.20853/31-1-979

Castles, S. (2010). Understanding global migration: A social transformation perspective. Journal of Ethnic and Migration Studies, 36(10), 1565-1586. doi:10.1080/1369183X.2010.489381

Chaka, J. G., \& Govender, I. (2017). Students' perceptions and readiness towards mobile learning in colleges of education: a Nigerian perspective. South African Journal of Education, 37(1), 1-12. doi:10.15700/saje.v37n1a1282

Chen, J., \& Mu, Z. (2010). The cross-national comparison of pre-service mathematics teacher education and curriculum structure. Journal of Mathematics Education, 3(1), 119-136. Retrieved from http://www.educationforatoz.com/images/_10_Jingan_Chen_and_Zhenwu_M u.pdf

Chisholm, L. (2009). The debate about re-opening teacher education colleges. An overview of research, policy and practice in teacher supply and demand 1994-2008. Cape Town: HSRC Press. Retrieved from https://www.researchgate.net/publication/234115611_An_Overview_of_Resea rch_Policy_and_Practice_in_Teacher_Supply_and_Demand_1994-2008

Darling-Hammond, L. (2006). Constructing $21^{\text {st }}$ century teacher education. Journal of Teacher Education, 57(X), 1-15. doi:10.1177/0022487105285962

Deacon, R. (2016). The initial teacher education research project: Final report. Johannesburg: JET Education Services.

Department of Higher Education and Training (DHET). (2015). National Qualifications Framework Act (67/2008): Revised policy on the Minimum Requirements for 
Teacher Education Qualifications. Government Gazette, 596(384487), 1-72, February 19.

Dominic, B. (2011). Women's education a tool of social transformation - A historical study based on Kerala society. International Journal of Scientific \& Engineering Research, 2(10), 1-7. Retrieved from http:/ / citeseerx.ist.psu.edu/viewdoc/download?doi=10.1.1.301.4017\&rep=rep1 \&type $=$ pdf

Du Toit, G. (2011). Conceptualising the re-design of the curriculum for teacher education. Acta Academica, 43(3), 107-131. Retrieved from https://hdl.handle.net/10520/EJC15535

Fleming, T. (2000). Habermas on civil society, lifeworld and system: Unearthing the social in transformation theory. Teachers College Record. Retrieved from http:/ / www.tcrecord.org/Content.asp?ContentID=10877

Geduld, D., \& Sathorar, H. (2016). Humanising pedagogy: An alternative approach to curriculum design that enhances rigour in a B.Ed. programme. Perspectives in Education, 34(1), 40-52. doi:10.18820/2519593X/pie. v34i1.4

Islam, F. (2012). Understanding pre-service teacher education discourses in communities of practice: A reflection from an intervention in rural South Africa. Perspectives in Education, 30(1), 19-29. Retrieved from https://journals.ufs.ac.za/index.php/pie/article/view/1729

Katitia, D. M. O. (2015). Teacher education preparation program for the $21^{\text {st }}$ century. Which way forward for Kenya? Journal of Education and Practice, 6(24), 57-63. Retrieved from https://files.eric.ed.gov/fulltext/EJ1078823.pdf

Kimathi, F., \& Rusznyak, L. (2018). Advancing professional teaching in South Africa: Lessons learnt from policy frameworks that have regulated teachers' work. Education as Change, 22(3), 1-25. doi:10.25159/1947-9417/4042

Kivunja, C., \& Kuyini, A. B. (2017). Understanding and applying research paradigms in educational contexts. International Journal of Higher Education, 6(5), 26-41. doi:10.5430/ijhe.v6n5p26

Khondker, H. H., \& Schuerkens, U. (2014). Social transformation, development and globalization. Sociopedia.isa, 1-14. doi:10.1177/205684601423

Korstjens, I., \& Moser, A. (2018). Series: Practical guidance to qualitative research. Part 4 : Trustworthiness and publishing. European Journal of General Practice, 24(1), 120124. doi:10.1080/13814788.2017.1375092

Machonin, P. (1996). Modernisation and social transformation in the Czech Republic. Czech Sociological Review, IV(2), 171-186. Retrieved from https://www.jstor.org/stable/41133014

Mahabeer, P. (2018). Curriculum decision-makers on decolonising the teacher education curriculum. South African Journal of Education, 38(4), 1-13. doi:10.15700/saje.v38n4a1705

Mashau, T. S., Mutshaeni, H. N., \& Kone, L. R. (2016). Teacher education: The South African context. International Journal of Educational Science, 14(1,2), 167-173. doi:10.1080/09751122.2016.11890490

Mlachila, M., \& Moeletsi, T. (2019). Struggling to make the grade: A review of the causes and consequences of the weak outcomes of South Africa's education system. International Monetary Fund Working Paper, 19(47), 1-61. Retrieved from https://cisp.cachefly.net/assets/articles/attachments/77568_wpiea2019047.pdf

Mohajan, M. (2018). Qualitative research methodology in social sciences and related subjects. Journal of Economic Development, Environment and People, 7(1), 23-48. Retrieved from https://mpra.ub.uni-muenchen.de/85654/ 
Mondal, A., Saha, A., \& Baidya, M. N. (2015). National curriculum framework for teacher education, 2009: A review of its perspectives and relevanceness. International Journal of Applied Research, 1(9), 776-778. Retrieved from https://www.allresearchjournal.com/archives/2015/vol1issue9/PartL/1-9164-423.pdf

Musa, J. M., Jimba, D. N., \& Ogundele, M. O. (2015). The role of teachers in transforming Nigeria: Challenges and the way forward. Asia Pacific Journal of Multidisciplinary Research, 3(2), 56-62. Retrieved from https:// www.APJMR-2015-3-2-008-The-roleof-teachers-in-transforming-Nigeria.pdf

Nomlomo, V., \& Sosibo, Z. (2016). From theory to practice: Beginner teachers' experiences of the rigour of the Postgraduate Certificate in Education programme. Perspectives in Education, 34(1), 199-215. doi:10.18820/2519593X/pie.v34i1.14

Osuji, S. N. (2009). Teacher education curriculum in Nigeria in the perspective of lifelong education. The Journal of International Social Research, 2(8) Summer, 296-301. Retrieved from https://www.sosyalarastirmalar.com/cilt2/sayi8pdf/osuji.pdf

Roberts, K., \& Dowell, D., \& Nie, J. (2019). Attempting rigour and replicability in thematic analysis of qualitative research data: A case study of codebook development. BMC Medical Research Methodology, 19(66), 1-8. doi:10.1186/s12874-019-0707-y

Sharma, R., \& Monteiro, S. (2016). Creating social change: The ultimate goal of education for sustainability. International Journal of Social Science and Humanity, 6(1), 72-76. Retrieved on https://unitec.researchbank.ac.nz/handle/10652/2949

Simion. K. (2016). Qualitative and quantitative approaches to rule of law research. Practitioner's guide. Retrieved from https://www.inprol.org/publications/15582/qualitativeand-quantitative-approaches-to-rule-of-law-research.

Sosibo, L. (2012). Exploring the views of educators and students on privileged knowledge domains in a teacher education programme: A case study. Journal of Education, 56, 139-169.

Retrieved

from https://www.researchgate.net/publication/268522876_Exploring_the_views_of _educators_and_students_on_privileged_knowledge_domains_in_a_teacher_ed ucation_programme_a_case_study

Thaba-Nkadimene, K. L. (2017). University of Limpopo student teachers' experiences and reflections during teaching practicum: An experiential learning theory. International Journal Educational Science, 17(1-3), 205-214. doi:10.1080/09751122.2017.1305735

Vaillant, D., \& Manso, J. (2013). Teacher education programs: Learning from worldwide inspiring experiences. Journal of Supranational Policies of Education, 1, 94-115. Retrieved from from http://www.denisevaillant.com/wpcontent/uploads/2018/08/JOSPOE_1_8.pdf

Wahyuni, D. (2012). The research design maze: Understanding paradigms, cases, methods and methodologies. JAMAR, 10(1), 69-80. Retrieved from https://www.researchgate.net/publication/256024036_The_Research_Design_ Maze_Understanding_Paradigms_Cases_Methods_and_Methodologies 